IntI Joumal of Public Administration, 32: 951-969, 2009

Copyright (C) Taylor \& Francis Group, LLC

ISSN 0190-0692 print / 1532-4265 online

Ren Rautledge

DOI: $10.1080 / 01900690903050984$

\title{
Trust in Government: A By-Product of NGO Intervention in Public Policy
}

\author{
Herrington J. Bryce \\ Mason School of Business and Affiliate, Thomas Jefferson Public Policy Program, \\ College of William and Mary, Williamsburg, Virginia, USA
}

\begin{abstract}
This article develops a theoretical rationale for the role of the rising number of nongovernmental organizations (NGOs), acting as independent agents, in influencing the risk exposure of governments to the loss of trust. In this article, trust is based on government performance consistent with citizen expectations. This performance-expectation connection is a concept in theories of democracy, trust, responsive government, and good governance. A role of the NGO in influencing trust in government is proposed centered on bringing government performance and citizen expectations into alignment.
\end{abstract}

Keywords: trust, NGOs, nonprofits, government performance, citizen expectation

As in other relationships, trust in government may reduce transactions costs such as the cost of compliance and monitoring, and it may facilitate voluntary citizen collaboration and cooperation with their government. (Cooper, Knotts, \& Brennan, 2008); (Wang, Wan, \& Warf, 2007); (Bryson, Crosby, \& Stone, 2006); (Cooper, Bryer, \& Meek, 2006); (Skelcher \& Mathur, 2005). Furthermore, trust in government may contribute to the latter's acceptability, stability,

I am particularly grateful for the suggestions of Sunglyul Kim, John Power, Tom Christensen and to June Daffeh. I am also grateful to the Department of Public Adnuinistration, Korea University, the Network of Institutes and Schools of Public Administration in Central Eastern Europe, to the Freedom House (Europe) for funding to discuss some of these ideas at the Central Eastern European University (Budapest, Hungary) and to the United Nations (Department of Economics and Social Affairs) for the opportunity to present some of these ideas at its 7th Global Forum. I am grateful to the Mason School of Business, College of William and Mary for its support. Finally, I thank the referee of this journal who helped give the document a much larger focus. I am solely responsible for errors.

Address correspondence to Herrington J. Bryce, Mason School of Business, Box 8795 College of William and Mary, Williamsburg, VA 23187-8795, USA; E-mail: herrington. bryce@mason.wm.edu 
longevity and policy choices. Thus, it can be assumed that governments and the public care about a deterioration of the public trust (Nye, Zelikow, \& King, 1997); (Behn, 2002); (Braithwaite, \& Levi, 1998); ( Badescu \& Uslander, 2003). This article presents a theoretical scheme through which the risk of the loss of trust in government may be reduced by the intervention of nongovernmental organizations (NGOs) in the public policy process.

It is assumed that the decline in the public's trust in government is a sequential process. The public does not trust today and instantaneously distrusts tomorrow. Accordingly, a central task of this article is to outline a sequential process that identifies specific opportunity points, modes, capacities, and legitimacy of intervention by NGOs that may reduce the risk of declining trust in government as the NGO pursues its own mission or responsibilities to those interests it represents as it operates within its own boundaries, i. e., mission, accountability, resources, capacity, responsibility such as in Kettl (2006).

This undertaking responds to several worldwide developments starting with the concerns for the declining trust in government and the push for openness and responsiveness (United Nations, 2007a, 2007b, 2007c). These developments also include a significant growth in NGOs worldwide and their (not always welcomed) intervention in public policy and in governance (OECD, 2003). It includes the policies of international development organizations to involve NGOs as potential agents for economic development and efficiency, social capital development and change as for example, the World Bank (Grootaert \& van Bastelaer, 2002).

It also includes the absence of a theory of NGO intervention precisely to reduce the risk of declining trust in government. Extant theories focus on contract (Hansmann, 1980), market (Weisbrod, 1986) or government (Moe, 1984; Salamon, 1985; Young, 1998). Failures (causing the NGO to be a substitute producer), or on intermediation particularly helping the underpowered to deal with government (Berger \& Neuhaus 1977); (Berger, Neuhaus, \& Novak, 1996), or on the roles of NGOs as adversary, substitute or complement to government (Young, 1998), or the role of nonprofits as incubators of social capital needed for the development of the elements of participatory democracy (Putnam, 2000).

In this article, the NGO may at times be doing any or all of these things because no deviation from mission is required. Indeed, the greater the success the NGO in its mission, the greater may be its legitimacy and skill and so its effectiveness in its intervention that could reduce the risk of declining trust in government. In addition, the greater the degree to which the organization has strong functioning social capital (common goals, values, cohesion, and participatory practice in the affairs of governance) the greater may be its effectiveness. Hence, an alternative phrasing of the question of this article is through what theoretical paradigm may this social capital impact (not social capital in general) but specifically trust in government--through what channels, using 
what tools, intervening at what points and producing what effect conducive to the trustworthiness of a government.

Thus, this article is organized around seven central questions. First, given the various ways in which trust is conceived, what is the most operationally useful definition for our purposes and why? Second, what may be the identifiable stages to which a public moves toward distrust of its government that could also allow preventative or corrective intervention by NGOs? Third, in what common government functions are the opportunities for meaningful intervention by NGOs most likely to occur and why?

Fourth, on what is the legitimacy of NGOs to intervene based? Fifth, what capacities do NGOs have in common that support assumptions of their abilities to perform within the meaning of the trust problem as defined? Sixth, what may be an orderly and predictable process of intervention of the NGOs utilizing these capabilities and based upon their legitimacy in democratic governance? Seventh, is it possible to bring these separate questions into a unified theoretical statement about how the intervention of the NGO in the democratic governance process may contribute to trust in government-even when the nonprofit is not an agent of the government? This article addresses each of these questions in order.

\section{AN OPERATIONAL DEFINITION OF TRUST IN GOVERNMENT}

Conditions conducive to distrust are natural to the operation of governments so that the risk of loss of trust is omnipresent. Rousseau long noted, distrust is a risk that is endemic to governments and institutions because they restrain natural expression. (Rousseau, 1792). Aside from Arrow's Impossibility Theorem showing how impossible it might be to have a unanimous choice among voters with different preferences, governance implies choosing within multiple constraints. The imperfection in compromise and the inability to satisfy all parties equally and simultaneously can lead to distrust as the needs of identifiable population segments are less than fully attended. Hence the seeds for disappointment that could lead to distrust are endemic in the very operation of governments as they always work within fiscal or other constraints that require trade-offs, i.e., winners and losers.

Among the many definitions of trust in the literature as for example in Gambetta (1988); (Sztompka, 1998), one definition of trust (and hence trustworthiness of government) is particularly applicable. It is trust as the reciprocal fulfillment of expectations. As political scientists, Hardin puts it, A expects B to perform in a specific way other than in B's own self-interest (Hardin, 1998, 2003). Applied to this article, the citizens expect that the government will perform in the interest of and consistent with the expectations of citizens and vice versa so that there is mutual trust. 
Trust here is specific-issue or event related. Thus, both parties may trust each other on an issue or event but not on another. Here we focus on government as the object of trust recognizing but not exploring the reciprocal feedback: Does the government trust the people?

Within this definition, the decline in trust of the government would derive from the latter's failure to live up to the expectations of its citizens based on its expressed and reasonably implied promises and the expectations of citizens. These promises or expectations may reside in a law, an electoral or administrative promise, in custom or misinformation. But the direct connections to an NGO intervention on this trust are influencing citizens' expectations and or influencing government performance so that they mesh. Indication of the amount or source of discordance can be obtained informally or by citizen satisfaction surveys. (Dalehite, 2008; Wichowsky \& Moynihan 2008). Hence, it is informed and actionable in a preventative or corrective manner.

The performance-expectation approach to trust is evidenced in a recent empirical finding that public participation (i.e., through NGOs) helps trust in government particularly as it relates to "administrative integrity" and "service competence" (performance). In at least one developing country, the Dominican Republic, trust of citizen shows a high, significant, and positive link to government "political and economic performance" (Espinal, Hartlyn, \& Kelly, 2006) and in the United States empirical results show a similar link to "economic performance and the public's assessment of the political process" (Keele 2005). Thus, the concept with which we work is practical and both theoretically and empirically grounded.

Arguably, the chronic loss of trust in government as defined above may not be an instantaneous response to any single incident or occurrence. In Table 1 I posit two likely antecedents (disappointment and disgruntlement as dissatisfaction is left unattended) in the movement toward distrust in government and the potential aftermath if this sequence is left unattended.

Specifically, in Table 1, I posit (based on my understanding of change) that there is first deep or extended dissatisfaction or disappointment in the government's performance based on public expectations. If this stage is left unattended and allowed to fester it may lead to disgruntlement; which if unattended, may lead to distrust. Distrust, left unattended, may generate reactions ranging from citizen disengagement and alienation (the passive citizens) to cries and actions for dismantlement by others (the activists).

"Dismantlement" may range from structural or procedural changes in the system of governance or in who governs how or for how long. In the very extreme, dismantlement could lead to the replacement of one despot with another as much as to the installation of a democracy. But (Tilly, 2005), unrelated to the concepts or theory in Table 1, has argued that the removal of an undemocratic government is no assurance that a democratic one will replace it. To assure a specific outcome, then, dismantlement and the distrust upon 
Table 1. Stages of Decay of Trust in Government and Aim of Intervention by NGOs

\begin{tabular}{|c|c|c|}
\hline $\begin{array}{l}\text { Stages to } \\
\text { distrust and its } \\
\text { aftermath }\end{array}$ & What occurs & $\begin{array}{c}\text { Aim of some curative or restorative actions } \\
\text { by NGOs that may increase trust in } \\
\text { government }\end{array}$ \\
\hline issatisfaction & $\begin{array}{l}\text { Meaningful citizen } \\
\text { expectations are not } \\
\text { met }\end{array}$ & $\begin{array}{l}\text { Avoiding deterioration to disgruntlement } \\
\text { partly by explication, mollification, } \\
\text { reasoning, making new or altered prom- } \\
\text { ises, getting alterations in government } \\
\text { performance and/or citizen expectations. } \\
\text { Dissatisfaction of some NGOs is matched } \\
\text { by satisfaction by others. Increase trust by } \\
\text { celebration of government performance } \\
\text { consistent with victor's expectations. }\end{array}$ \\
\hline Disgruntlement & $\begin{array}{l}\text { Dissatisfaction is left } \\
\text { unattended and } \\
\text { allowed to fester. }\end{array}$ & $\begin{array}{l}\text { Avoiding deterioration to distrust partly by } \\
\text { doing all of the above but emphasizing } \\
\text { and nurturing hope and purpose. People } \\
\text { may still be dissatisfied but can be made } \\
\text { to "understand." }\end{array}$ \\
\hline istrust & $\begin{array}{l}\text { Disgruntlement turns } \\
\text { to lack of trust in } \\
\text { government's } \\
\text { intent, or capability } \\
\text { to be satisfactorily } \\
\text { responsive to those } \\
\text { who are disgruntled. }\end{array}$ & $\begin{array}{l}\text { Arresting deterioration by all of the above, by } \\
\text { assisting improved government } \\
\text { performance to match expectations on a } \\
\text { demonstrable and sustainable basis. "Show } \\
\text { me that we can rely on the government } \\
\text { to adequately respond to our needs and our } \\
\text { exposure to natural or human risks." } \\
\text { "What am I going to get out of my efforts? } \\
\text { "Why bother?" "What can the NGO do?" }\end{array}$ \\
\hline Disengagement & $\begin{array}{l}\text { Citizens become disin- } \\
\text { terested, } \\
\text { indifferent, } \\
\text { alienated; find no } \\
\text { value in } \\
\text { engagement with } \\
\text { government and in } \\
\text { the public policy } \\
\text { process. }\end{array}$ & $\begin{array}{l}\text { Restoration of trust aimed to energize } \\
\text { citizens by demonstrating not only } \\
\text { change in government performance but } \\
\text { also the benefits that can accrue to civic } \\
\text { involvement; thus, affecting expectations. } \\
\text { "Engagement and involvement are worth } \\
\text { it." "There is hope." "The system needs } \\
\text { you to participate." "You can make a } \\
\text { difference." "Let your voice be heard." } \\
\text { "Your vote counts." }\end{array}$ \\
\hline Dismantlement & $\begin{array}{l}\text { Citizens seek change } \\
\text { because engagement } \\
\text { with government is } \\
\text { felt to have failed, } \\
\text { been thwarted, not } \\
\text { rewarded, and access } \\
\text { is unavailable. }\end{array}$ & $\begin{array}{l}\text { Restoration of trust principally by advocating } \\
\text { and accomplishing change in incumbency, } \\
\text { the system, and/or its processes. Restoring } \\
\text { and heightening expectations of "better" } \\
\text { government performance through change. } \\
\text { "Let's get rid of them." "Let's fix the system } \\
\text { where it is broken." "Let's replace it." }\end{array}$ \\
\hline
\end{tabular}

Source: The author. 
which it is based must be managed because even the most dramatic democratic change can lead to disappointment and the possibility of distrust if there is a severe disconnect between what citizens expect and what can realistically be achieved.

The table also describes the intervention by NGOs at each point. These range from dealing with dissatisfaction and disgruntlement through explanation as to how the policy may work advantageously--how those who are dissatisfied may take advantage of certain features, to extracting promises from government that limit the impact of its action or promises of future compromising action. Note that these types of interventions do not require the NGO to be in a master-servant relationship or in the employ of the government (although it can). The NGO need only be representing its own purpose or the interest of those it represents. Therefore, the NGO's contribution to trust in government is often an unintended consequence of its exercise of its own self-interest or the special interest of those whose concerns and benefits it representsunions, business and professional associations, civic, educational, welfare, and advocacy and action groups such as environmental groups are examples. They can influence trust in government to the extent that they can align government performance with the expectations of citizens and what the latter thinks is in its best interest.

\section{THE PUBLIC POLICY PROCESS AS A POINT OF INTERVENTION}

Governments conduct a variety of functions subject to the sequence in Table 1 . To effectively manage trust in government, we must locate where in the governance process events that are susceptible to the impact of intervention by NGOs are most likely to occur. One way of looking at this fact is by levels of government, i.e., centers of responsibility for discharging a specific activity. When government is highly centralized, the central authority becomes the principal (if not the only) center of expectations; it decides, directs, and sets the terms of distribution. Under these circumstances, the relevance of trust in lower levels of governments does not disappear but is diminished.

But in highly decentralized systems, power, authority and responsibility are diffused so that the relevance of "government" in "trust in government" varies because of the location of power, authority, responsibility and its alignment with resources. The citizens share some of these responsibilities so that the performance of the government is in part contingent on the performance of the citizens themselves as well as upon the clarity and reasonableness of citizen expectations.

Yet, there are certain common functions and criteria of performance that generally constitute good democratic governance. Table 2 distinguishes trust in government as in its integrity - its proneness to deceit and corruption-from trust in government as in its capacity or capability to manage the bureaucracy 
Table 2. Objects of Trust in Government by Function

\begin{tabular}{ll}
\hline Object of trust & \multicolumn{1}{c}{$\begin{array}{c}\text { Some questions we ask in deciding on } \\
\text { trustworthiness }\end{array}$} \\
\hline $\begin{array}{l}\text { Integrity } \\
\text { Administrative Competence }\end{array}$ & $\begin{array}{l}\text { Is it corrupt? Is it deceitful? } \\
\text { Does it operate efficiently? How does it manage } \\
\text { the bureaucracy? }\end{array}$ \\
Judicial Legislative & Is it fair, arbitrary, consistent, and obedient to the \\
& rule of law? \\
Electoral Process & Is it representative, transparent, open, reasonable? \\
Public Policy Process & Is it fair? Is it inclusive? \\
& How does it make and implement policy?
\end{tabular}

Source: The author.

during the normal course of events or in crisis. It distinguishes trust in the way the government is managed from trust in its judicial and legislatives systems. It also distinguishes trust in government in the public policy from the electoral process - its openness, faimess, and inclusiveness in leadership choicesfrom trust in its management and performance in the public policy processthe government's making and implementing decisions affecting the welfare of the public. This article points to the last-the public policy process-as the principal locus of the risk that the government will lose the public's trust due to performance inconsistent with citizen expectations.

The rationale is as follows. All NGOs can operate in the public policy process. At least in countries using the United Kingdom and Wales (based on the Charles Act of 1993 which in turn is based on the Preamble to the Charities Uses Act of 1601) or the United States model of nonprofit law, Section 501(c) of the Internal Revenue Code, the involvement of NGOs in the political process (defined in law as the influencing of elections) is prohibited; but lobbying (affecting the design and implementation of law and regulations) is not. This section of the Code also prohibits political activities by NGOs except for Section 527 organizations-political parties and committees.

Furthermore, campaigns often highlight flaws as well as exploit and sow disappointment and discontent in the incumbent government as a way of attracting voters often making the electoral process an incubator of distrust more so than trust. In the public policy process distrust may also be imbued, but in that process policy is debated (information), decided upon (lobbying), designed (planning and drafting), implemented (doing), continued or amended (evaluation and lobbying), or discarded.

The public policy process is also the venue in which promises as policy, policy as expectations, and policy as performance occur-making it a natural basis of Hardin's definition of trust as described earlier. In addition, the public 
policy process continuously links citizens and their governments-unlike the periodic intervention of the electoral process. The public policy process gives meaning to the electoral process. Once elected, the citizens judge whether performance matches expectations and promises. The public policy process is therefore philosophically and pragmatically a natural breeding ground for distrust in government through the inconsistency of its performance with citizen expectations.

But, the public policy process can also be a scapegoat. To illustrate, a government agency that is seen as inefficient may be the victim of resource diversion-never getting the resources it needs to meet the expectations of citizens. Yet, it is the agency's lack of performance that disappoints and causes distrust and distress. Similarly, distrust in the public process may result, not from the process as from the ability of some individuals to legally, even "ethically," exploit it. In this case, changing the public policy or its process is not the solution, but changing or equalizing effective access to it (e.g., through NGOs) may be.

Table 3 reflects that trust in government as it relates specifically to the public policy process connotes a flow of positive and negative sentiments that increases or decreases the stock of trust people have accumulated in their governments. These flows of sentiments can change the size, spread, intensity, fragility, and depth of this accumulated stock of trust.

Since the public policy process is on going, the government's exposure to the loss of trust is on going. But the nature of the exposure differs from stage to stage in the public policy process; i.e., trust that the government will listen, but distrust that it will respond appropriately; or trust that it may initially be responsive but not sufficiently supportive, sustaining or self-correcting.

Thus, in Table 3, intervention by NGOs is more than gathering and providing information. The availability of information is not sufficient to trust that the government will receive it, assess it with due diligence, fairly, apolitically, and accurately. Hence, solving the basic asymmetric information problem while important may not be sufficient and does not exhaust the NGO's capacity. The NGO can do more.

Trust in government through the public policy process is based not only on the government's willingness to obtain information-recognizing that information is needed in all phases of policy from conceptualization to implementation and modification (Verba \& Nie, 1972), but in its wisdom to judge credibility, urgency, and significance; to weigh the consequences of various options and to follow this with an appropriate program of funding and implementation; to harness the citizen involvement that is necessary to co-produce the results (not just support it) and the willingness or capability of the government to amend policy as required. This is the sequence of Table 3 showing the potential role of the $\mathrm{NGO}$ in each step.

Effective intervention requires trust by government in the NGOs. This is partly an incumbency problem. Each change in government incumbency is 
Table 3. Government Exposure to Loss of Trust: From Receiving Information to Taking Action and the Preventative Intervention of NGOs at Each Step

\begin{tabular}{|c|c|c|}
\hline $\begin{array}{l}\text { Steps in risk exposure } \\
\text { from information to } \\
\text { policy action }\end{array}$ & $\begin{array}{l}\text { Manifestation of distrust } \\
\text { by citizens }\end{array}$ & $\begin{array}{c}\text { Trust-managementstrategies } \\
\text { of NGOs }\end{array}$ \\
\hline $\begin{array}{l}\text { To hear and understand } \\
\text { all citizens with } \\
\text { diverse views, senti- } \\
\text { ments, and dispersed } \\
\text { over a wide space. }\end{array}$ & $\begin{array}{l}\text { Expression of loss of trust } \\
\text { that the government } \\
\text { listens or understands } \\
\text { and that involvement } \\
\text { matters. }\end{array}$ & $\begin{array}{l}\text { The NGO as a channel } \\
\text { for communicating } \\
\text { interests, explaining and } \\
\text { conciliating. }\end{array}$ \\
\hline $\begin{array}{l}\text { To formulate policies } \\
\text { reflecting not merely } \\
\text { power, but costs and } \\
\text { benefits and minimiz- } \\
\text { ing the extent and } \\
\text { depthofdissatisfaction } \\
\text { and disgruntlement } \\
\text { leading to distrust. }\end{array}$ & $\begin{array}{l}\text { Expression of loss of trust } \\
\text { that the government can } \\
\text { deliberate expediently } \\
\text { and decide fairly and } \\
\text { clearly. }\end{array}$ & $\begin{array}{l}\text { NGOs as screening bodies: } \\
\text { ideas tested, preferences } \\
\text { (positive and negative) } \\
\text { and acceptability of policy } \\
\text { revealed in early warning. }\end{array}$ \\
\hline $\begin{array}{l}\text { To finance and to provide } \\
\text { adequate resources } \\
\text { to meet policy } \\
\text { requirements and aims } \\
\text { on a timely basis. }\end{array}$ & $\begin{array}{l}\text { Expression of loss of trust } \\
\text { that the government can } \\
\text { and will adequately } \\
\text { finance or deliver over } \\
\text { time as government } \\
\text { priorities change for } \\
\text { whatever reason. }\end{array}$ & $\begin{array}{l}\text { NGO's commitment, use of } \\
\text { voluntary and private } \\
\text { resources, and substitution } \\
\text { of deductions and } \\
\text { exemptions for direct } \\
\text { government expenditures. }\end{array}$ \\
\hline $\begin{array}{l}\text { To receive and act upon } \\
\text { complaints in a timely } \\
\text { and satisfactory } \\
\text { manner even when } \\
\text { project is being done } \\
\text { by outside contractors. }\end{array}$ & $\begin{array}{l}\text { Expression of loss of trust } \\
\text { that the government } \\
\text { cares, represents the } \\
\text { best interests of } \\
\text { citizens, is not corrupt. }\end{array}$ & $\begin{array}{l}\text { NGO as monitor, } \\
\text { contractor, advocate. }\end{array}$ \\
\hline $\begin{array}{l}\text { To mollify, satisfy, } \\
\text { reason, and to timely } \\
\text { and orderly change } \\
\text { incumbency and } \\
\text { policies and to } \\
\text { provide for orderly } \\
\text { readjustment. }\end{array}$ & $\begin{array}{l}\text { Expression of loss of trust } \\
\text { that government cares, } \\
\text { is responsive, amenable } \\
\text { to change. Expressions } \\
\text { of alienation: "Nothing } \\
\text { matters." }\end{array}$ & $\begin{array}{l}\text { The NGO as partner, social } \\
\text { agent, creator of social } \\
\text { capital-facilitating civic } \\
\text { participation and so } \\
\text { increasing trust in } \\
\text { government if public } \\
\text { process allows. }\end{array}$ \\
\hline
\end{tabular}

Source: The author.

normally matched with a set of NGOs with sympathetic ideologies. The "in" NGOs help to influence trust in government often by rationalizing the government's performance because it is not inconsistent and often identical with the NGOs. 


\section{THE CAPACITIES OF THE NGO}

What is the capacity of the NGO to contribute to the management of the public trust in government by managing the discordance between citizen expectations and government performance so that disappointment does not turn into distrust as the government makes and implements public policy?

\section{Capacity as Range of NGO Functions}

As shown in Table 4, and as stated earlier as a reflection of current theory, NGOs can be providers of products or services independently or in collaboration with governments, firms, and other NGOs. They can attract resources that may not be available to the government (even by confiscation since some come from abroad) yet are needed to improve the welfare of its citizens (food and medical services); and in so doing, reduce dissatisfaction with government. They can assume portions of certain social risks (caring for the poor)-reducing a

Table 4. Capabilities NGOs Bring to the Public Policy Process Applicable to the Management of the Trust in Government

\begin{tabular}{|c|c|}
\hline Function & Description \\
\hline Information: & Gathering of information from needs to innovative research \\
\hline Diffusion: & $\begin{array}{l}\text { Disseminate information, aims, values, political and other } \\
\text { philosophies }\end{array}$ \\
\hline Evaluation: & Judging and monitoring the efficacy of policy \\
\hline Signaling: & $\begin{array}{l}\text { Calling attention to needs, problems, opportunities, } \\
\text { and giving early warning }\end{array}$ \\
\hline Organization: & $\begin{array}{l}\text { Organize groups and persons for or against a position, } \\
\text { action, or regime }\end{array}$ \\
\hline Contention: & Opposing policy, policymaking, or policy makers \\
\hline Screening: & $\begin{array}{l}\text { Locus of discourse, refinement, sanctioning and selecting } \\
\text { of options and reactions }\end{array}$ \\
\hline Intermediation: & $\begin{array}{l}\text { Facilitating access of the people through government } \\
\text { processes and agencies }\end{array}$ \\
\hline Brokering: & $\begin{array}{l}\text { Working with both people and government to make things } \\
\text { happen between them }\end{array}$ \\
\hline Representation: & $\begin{array}{l}\text { Advocating, defending, and rationalizing positions or } \\
\text { purposes }\end{array}$ \\
\hline Collaboration: & $\begin{array}{l}\text { Working with governments and other entities toward } \\
\text { a public product }\end{array}$ \\
\hline Provider: & $\begin{array}{l}\text { Provider of output or service using governmental } \\
\text { and nongovernmental finance }\end{array}$ \\
\hline Regulation: & Sanction behavior or performance \\
\hline
\end{tabular}

Source: The author. 
source of dissatisfaction. They can be intermediaries that facilitate access by the public and they can be brokers that work to make things happen by bringing parties together e.g. sponsoring fora between policymakers or administrators and the public to communicate expectations and limitations of both sidesminimizing policy schocks. They can be monitors such as "watchdog agencies."

Of course, they can represent a particular interest, party, or policy-related point of view (unions, cooperatives, business, and other interest groups). In addition, they can gather information and disseminate it through public and private channels. They can be contentious (pro this or anti that). They can organize on behalf of or against a cause (leagues and associations). They can screen and refine information through discourse and signal preferred options (educational and informational organizations). They can certify, sanction, and thereby control or signal appropriate behavior and also advance conformity with public policy to promote the best interest of citizens (medical, law, trade and other professional boards). The capacity of NGOs to operate in any or all of these capacities places them in a position to influence government performance from its conception to its implementation and modification and to shape or express citizen expectations.

\section{The Source of Empowerment}

How is the NGO empowered to use these inherent capabilities on behalf of the public or subgroup in the public policy process? NGOs are organizations voluntarily formed by citizens on the basis of their commitment to serve a specific purpose or mission. Broadly speaking and consistent with current theories, this mission might be the result of the failure of markets or governments; or it might be to substitute, complement, or alternative to government. It may also be a substitute for individuals (not just government). (Produhan, 1851) noted the increasing role of institutions as representatives of people in the governance process in lieu of individuals representing themselves and Alexis de Tocqueville writes in "Relation of Civil to Political Associations" Democracy in America, Volume 2, Section 2:

In all the countries where political associations are prohibited, civil associations are rare. It is hardly probable that this is the result of accident ... there is a natural and perhaps a necessary connection between these two kinds of associations ... Civil associations ... facilitate political association ... political association singularly strengthens and improves associations for civil purposes (1833).

In more recent years, it has been argued that a principal function of NGOs is to mediate the course of government particularly for those who cannot do so for themselves - principally the poor. But in this section of the paper, we are 
concerned with the empowerment to act within a state or political jurisdiction. Constitutionally, such empowerment is accorded by a state - not by the citizens. It is the state that empowers through licensing and that charters an organization to function in specific ways (authorities designated within the charter or license) within its domain.

Accordingly, the empowerment of the NGO is based on the following. The government's granting of a charter to the NGO is tantamount to its giving it a license of empowerment to function as specified in its mission. The government's giving of tax exemption to the NGO is tantamount to its concluding that the mission is of sufficient public import to be publicly financed. This is the legal basis for the NGO's empowerment to function as described: The government formally grants and certifies a written charter giving the NGO's the powers and authority to act. Therefore, the engagement of the NGO in the public policy process is not based on a palliative motive, but on an empowerment, through chartering or licensing.

\section{The Foundation of Legitimacy}

To be effective, to be taken seriously in the public policy process, it is not enough for the NGO to be empowered but it must have legitimacy. NGOs cannot be assumed to be unbiased, apolitical, or accurately representative of the public's interest-even that segment that it purports to represent (Geva-May, 2002); (Hoppe, 2002); (Taylor, 2005). Policy makers must feel that the NGO represents an informed point of view and the interests of citizens specifically on the issue upon which they intervene.

Legitimacy is a narrow concept because the public policy maker does not necessarily ask if the organization represents the citizen in general on all issues, but whether it represents with respect to the specific issue at hand. The power and relevance of legitimacy relates, in part to the type of participation (Fung, 2006). The legitimacy of a labor union is with respect to its representing its members on issues related to their work and profession and reflected in the votes or support of members.

The lack of legitimacy of an NGO in the public policy process is likely to be short-lived if its members or members of the public are informed of its representations and capable of voluntary action. They can refuse to support the organization. Where the NGO is a membership organization such as a cooperative, a union, or an association, the members may quit (Olson, 1965). Citizens may also support or join rival organizations. Furthermore, to the extent that the organization continues not to comply with its mission, its charter can be revoked by the state. Therefore, the foundation of legitimacy is the ability of the organization to fulfill its mission-not to government-but to the citizens who voluntarily form and support it. Its contribution to trust in government is therefore a by-product of its exercise of its mission to citizens. 


\section{Networks}

The NGO's influence is related to its ability to draw upon networks and coalitions held together by strongly shared values (Schlager, 1995); (Schlager \& Bromquist, 1996); and for which (Sobeck, 2003) provides empirical evidence. Policy networks are relational (Gould, 2003) and provide a brokerage function (Dani, 2003) and may play a variety of roles in the public policy process (Kisby, 2007). Each NGO can be considered to be part of a complex web of partially intersecting sets of NGOs.

The more dense and differentiated the NGOs in a country space (given its fixed borders) the less likely the probability of complete uniqueness or unrelated interest to others in that space. On any issue, therefore, there are other NGOs within the same space with whom an NGO finds common cause even if the primary mission is different. Thus the producers of spirits may finance NGO programs against driving under the influence of alcohol because of a common interest in public safety.

Within any fixed country space there is constant rearranging of networks in response to changes in public policy considerations. These rearrangements and intersections also occur because, as public choice teaches about lobbying and rent seeking, NGOs can trade support: "We'11 support and get others to support you on this one if you will do the same for us on our issue." With this latter behavior, networking can occur even when the interests in a policy issue are not identical. Thus, the diversity and large number of NGOs even covering a single subject such as the environment can connect associated interests into a network of common and shared interests, knowledge, and other resources (Mikkelson, 2006) (bridging social capital). Hence, networks (some crossborder) can dramatically magnify the potential resources NGOs bring to the public policy process on specific issues (Tarrow, 2005).

\section{First and Second Order Legitimacy}

Special problems arise when through networks or other means NGOs form coalitions or federations for the purpose of having an impact on the public policy process such as through negotiation or lobbying. This introduces what may be called first and second order problems of legitimacy. First, each NGO has to be legitimatized by those it represents-that is-first-order legitimacy. Then the coalition it enters into with others must, as a collective body, be legitimatised by each NGO in the coalition-second-order legitimacy. And the moral hazard and risk of loss of trust can be as great for the NGO and its coalition as it is for the government; for they too must perform to meet the expectations for which they were formed. Hence, normally there should be a disincentive for the NGO or coalition (even if rent-seeking with respect to the government) to deviate from its path just to increase trust in government. 


\section{SPECIFIC POINTS AND TOOLS OF INTERVENTION IN THE PUBLIC POLICY PROCESS}

Opportunities for NGO intervention should be identifiable and predictable. In this section, we identify and describe specific points in the public policy process where NGO intervention may be useful in shaping a policy product that is consistent with public expectations and therefore trust in government. At each point, the $\mathrm{NGO}$ is acting in its own self-interest (i.e., carrying out its mission) or that of the citizens with an impact on government performance and/or citizen expectations influencing trust in government.

Table 5 notes that in the formulation of policy, civic engagement by NGOs for example through representative public hearing, can be an important source of information for defining need, expected involvement, and specifying the expectations of government performance. Another strategy an NGO may use at this stage is lowering expectations from government policy (partly to protect its own image) or heightening it so as to put pressure on the government. In either case, citizen expectation is being influenced and so too government performance (policy product or service design).

In the second stage, the NGO may impact how the policy is implemented. It may help in rule making, and it might implement policy. One of the effects of civic involvement in the design as well as in the implementation stage is to potentially shift some of the risks and responsibility of failure (and therefore a

Table 5. Points and Forms of Risk-Management Intervention by NGOs in the Public Policy Process

\begin{tabular}{ll}
$\begin{array}{l}\text { Points } \\
\text { of intervention }\end{array}$ & \multicolumn{1}{c}{ Forms of intervention } \\
\hline $\begin{array}{c}\text { Initial Policy } \\
\text { Formulation }\end{array}$ & $\begin{array}{c}\text { Information gathering, group formation, discussion, taking of } \\
\text { group position, cooperative action, lobbying, commenting, } \\
\text { information dissemination, influencing legislative drafting } \\
\text { and voting. } \\
\text { Financing, facilitating, popularizing and carrying out policy } \\
\text { through programs. } \\
\text { Inplementation }\end{array}$ \\
$\begin{array}{c}\text { Monitoring and } \\
\text { Evaluation }\end{array}$ & $\begin{array}{c}\text { Technical and sentimental information gathering, influencing } \\
\text { and advancing new policy initiatives and modifications of } \\
\text { and Innovation }\end{array}$ \\
Policy Revision & $\begin{array}{c}\text { extant policies. } \\
\text { Information gathering, discussion, advocacy, lobbying, } \\
\text { commenting, information dissemination, influencing } \\
\text { legislative drafting and voting-helping government to } \\
\text { chart course and to win acceptance of revision }\end{array}$
\end{tabular}

Source: The author. 
cause of disappointment leading to distrust) away from the government and to those NGOs that participated in the design, neglected to do so but should have, or participated in the implementation of the policy. In the implementation phase, the NGO is focused on performance.

A third stage of intervention relates to continuous experimentation, innovation and in-process adjustments and modifications to how the policy is applied as partly through NGO monitoring. Trust in government at this stage is derived from the speed as well as the direction of government response. But the monitoring and the public insistence on modifications by the NGO would invariably impact trust in government. Whether this is positive or negative would depend upon how the government reacts. In this phase, the NGO directs its energies to both performance (i.e., better product and delivery systems) and expectations.

Finally, in Table 5 we note that the public policy process involves an end period of evaluation provided for by sunset rules, and required reauthorization. At this point, public trust depends upon the ability or willingness of the government to listen, to discard bad policy, and to modify the offending ones (or parts). NGOs can record and communicate common public experiences and suggest appropriate modifications based on actual experience and expectations. Importantly, this is tied to the belief that the government will learn, adjust, and continue a policy that has been successful and still needed. At this stage the NGOs can influence both performance and expectations.

The intervention of the NGO is meaningless if there is no demonstrable government commitment to initiate, to modify or to (dis-) continue bad policy and adopt good ones-if no corrective or preventive response occurs. Noncommitment likely breeds disappointment in its revelation, followed eventually by distrust, call for disengagement (among the passive citizens) and dismantlement among the activists.

\section{A SIMPLE THEORY FOR NGO INTERVENTION IN THE PUBLIC POLICY PROCESS}

At any point in time, a government enjoys a store of trust that may increase or diminish as citizen become disappointed in policy decisions or implementation. Some citizen disappointment is certain because governments, operating within constraints, make choices and trade-offs that leave some segments of the citizenry disappointed. The central task, therefore, is managing these disappointments so that they do not lead to chronic distrust.

In an environment of

(a) common topical interest between the state and the NGO and the latter and the citizens of the State, 
(b) of reciprocal confidence that the expectations of one party (citizens, $\mathrm{NGO}$, or government) condition the performance of the other,

(c) where the NGO has capacity, legitimacy and empowerment as defined, and

(d) there are identifiable and predictable points of intervention in the public policy process in particular, the need for a servant-master relationship (the NGO as agency of the State) is largely replaceable by the NGO as modifier of the people's expectations and/or the performance of the State.

By aligning expectations and performance, the risk of declining trust in government is reduced.

By implication, by using the same mechanism in this article, the NGO by its own intent or lack of competency, can increase the imbalance so that citizen expectations are beyond or different to government performance. This would cause a rise in the risk of declining trust in government and ultimately its dismantlement. This outcome is not necessarily bad if it is a result of an "awakening" to the incompetence or mal-performance of a government that is not trustworthy.

\section{DISCUSSION AND CONCLUSION}

NGOs are organizational forms that accommodate public participation in the dialogue and practice of governance in a democratic society. In general, the literature presumes that public participation or engagement in government is good. This paper does not question that proposition. Rather, it proposes a theoretical argument linking NGO intervention in the process of governance to the level of the public's trust in a government even when the NGO is seeking its own self interest or that of its membership or some dominant segment therefore and not operating as an organ, captured agent, agency, or servant of the state. Trust in government need not be the intent of the NGO, it might be an unintended by-product of the efficiency with which an NGO does its work in the public policy process.

The article is normative in the sense that it does not seek to evaluate the content or message of this intervention-recognizing that democratic processes are open to varying, conflicting, and even contentious views, and also that trust can be abused. Rather, it begins with a strict definition of trustworthiness: government performance consistent with citizen expectations. It then proceeded to articulate specific steps in which the inconsistency between expectations and performance may lead to distrust and even call for dismantlement. Each step in this process is an identifiable an opportunity point of intervention by NGOs to stem (or foment) distrust with identifiable tools, capacities, and legitimacies of the NGOs to influence performance or expectations or both in identifiable stages in the public policy process. 


\section{REFERENCES}

Badescu, G., \& Uslander, E (eds.) (2003). Social capital and democratic transition. London: Policy Press.

Behn, P. D. (2003). Government performance and the conundrum of public trust. In J. D. Donahue, \& J. S. Nye, Jr. (eds.) Market-based governance (pp. 325-348). Washington, DC: Brookings Institution Press,

Berger, P., \& Neuhaus, R. (1977), To empower people: The role of mediating structures in public policy. Washington, D.C., American Enterprise Institute for Public Policy Research.

Berger, P., Neuhaus, R, \& Novak, R. (eds.). (1996). To empower people: From state to civil Society. Washington, DC: American Enterprise Institute for Public Policy Research.

Braithwaite V., \& Levi, M. (1998). Trust \& governance. New York: Russell Sage Foundation.

Bryson, J., Crosby B., \& Stone, M. (2006). The design and implementation of cross-sector collaborations: Propositions from the literature. Public Administration Review, 66 (Special), 44-56.

Cooper T. L., Bryer T. A. \& Meek, J. A. (2006). Citizen-centered collaborative public management. Public Administration Review, 66 (Special Issue), 76-89.

Cooper, H., Knotts, G., \& Brennan, K. (2008). The importance of trust in government for public administration: The case of zoning. Public Administration Review, 68 (3), 459-468.

Dalehite, E. (2008). Determinants of performance measurement: An investigation into the decision to conduct citizen surveys. Public Administration Review, 68 (5), 891-907.

Dani, M. (2003). Leaders or brokers: Positions and influence in social movement networks. In M. Diani, \& D. McAdams (eds.), (2003) Social movememt and networks: Relational approaches to collective action (pp. 105-122). Oxford: Oxford University Press.

de Tocqueville, A. Relation of civil to political associations. In Democracy in America, Vol. 2, Section 2. Henry Reeves translation, 1899, offered electronically by the American Studies Program, University of Virginia, Charlottesville, VA 1997. http://xroads. virginia.edu/ HYPER/DETOC/colophon.html

Espinal, R., Hartlyn, J., \& Kelly, J. (2006). Performance still matters: Explaining trust in government in the Dominican Republic Comparative Political Studies, 39 (2), 200-223.

Fung, A. (2006). Varieties of participation in a complex governance. Public Administration Review. 66 (6), 10-20.

Gambetta, D. (ed.). (1988). Trust: Making and breaking cooperative relationships. Oxford: Oxford University, UK Basil Blackwell.

Geva-May, I. (2002). Cultural theory: The neglected variable in the craft of policy analysis. Journal of Comparative Policy Analysis 4 (3), 243-263. 
Gould, R. V. (2003). Why do networks matter: Relational and structural interpretations. In Diani, M., \& McAdams, D. (eds)., Social movememt and networks: Relational approaches to collective action (pp. 105-122). Oxford: Oxford University Press.

Grootaert, C., \& van Bastelaer, T. (eds.), (2002). Understanding and measuring social capital: A multidisciplinary tool for practitioners. Washington, DC: The World Bank.

Hansmann, H, (1980). The role of nonprofit enterprise. The Yale Law Journal, $89,835-898$.

Hardin, R. (1998). Trust in government. In Braithwaite V., \& Levi M. (eds.), Trust \& governance (pp. 10-11). New York: Russell Sage Foundation.

Hardin, R. (2003). Trust and trustworthiness. New York: Russell Sage Foundation.

Hoppe, R. (2002). Culture of public policy problems. Journal of Comparative Policy Analysis, 4 (3), pp. 305-327.

Keele, L. J. (2005). Macro measures and mechanics of social capital. Political Analysis 3 (2), 139-156.

Kettl, D. F. (2006). Managing boundaries in American administration, the collective imperative. Public Administration Review, 66,10-20.

Kisby, B. (2007). Analyzing policy networks: Toward and ideational approach. Policy Studies, $28(1), 7$.

Mikkelson, M. (2006). Policy network analysis as a strategic tool for the voluntary sector. Policy Studies, 27 (1), 17.

Moe, T. (1984). The new economics of organization. American Journal of Political Science, 28 (4), 739-777.

Nye, J, Zelikow, P. D., \&. King, D. C. (eds.), (1997). Why people don't trust governments. Cambridge, MA: Harvard University Press.

OECD. (2003). The non-profit sector in a changing economy (pp. 10-27). Paris: The Organization for Economic Co operation and Development.

Olson, M. (1965). The logic of collective action: Public goods and the theory of groups, (p. 35). Cambridge, MA: Harvard University Press.

Putnam, R. (2000). Bowling alone: The collapse and revival of American community. New York: Simon \& Schuster.

Produhan, P. J. (1851). General idea of the revolution in the nineteenth century.

Rousseau, J. J. (1962). Social contract: Principles of political rights. See eBooks from Adelaide, 2005. http://ebooks.adelaide.edu.au/r/rousseau/ jean_jacques/r864s/

Salamon, L. M. (1995). Partners in public service: Government-Nonprofit relations in the modern welfare state. Baltimore: Johns Hopkins University Press.

Schlager, E. (1995). Policy making and collective action, defining coalitions with the advocacy coalition framework. Policy Sciences. 28, 242-270.

Schlager, E., \& Blomquist, W. (1996). A comparison of three emerging theories of the policy process. Political Research Quarterly, 49(3), 651-672. 
Skelcher, C., Mathur, N., \& Smith, M. (2005). The public governance of collaborative spaces: discourse, design and democracy. Public Administration, $83(3), 573-596$.

Sobeck, J. (2003). Comparing policy process frameworks, what do they tell us about group membership and participation for policy development? Administration and Society. 35 (3), 350-374.

Stone, C. (2005). Rethinking the policy-politics connection. Policy Studies, 26 $(3-4), 241$.

Sztompka, P. (1999). Trust: A sociological theory. Cambridge: Cambridge University Press.

Tarrow, S. (2005). The new transnational activism. Cambridge: Cambridge University Press.

Taylor, D. (2005). Governing through evidence: Participation and power in policy evaluation. Journal of Social Policy, 34(4), 601-619.

Tilly, C. Trust and rule (chp. 2). New York: Cambridge University Press.

Tilly, C. (2005) Social movements 1768-2004. Vancouver: University of British Columbia Press.

United Nations, (2007a). Public administration and democratic governance: Governments serving citizens: New York: United Nations.

United Nations (2007b). World public sector reports, people matter: Civic engagement in public governance. New York: United Nations.

United Nations (2007c) Toward participatory and transparent governance: New York: United Nations.

Verba, S., \& Nie, N. (1972). Participation in America. New York: Harper and Row.

Wang, X. H., \& Wan Warf, M. (2007). When public participation in administration leads to trust: An empirical assessment of managers' perceptions. Public Administration Review, 67(2), 265-278.

Weisbrod, B. A. (1986). Toward a theory of the voluntary nonprofit sector in a three-sector economy. In Rose-Ackerman S, (ed), The economics of nonprofit institutions (pp. 21-44). New York: Oxford University Press.

Wichowsky, A., \& Moynihan. D. P. (2008). Measuring how administration shapes citizenship: A policy feedback perspective on performance management. Public Administration Review, 68 (5) 908-920.

Young, D. R. (1998). Complementary, supplementary, or adversarial? A theoretical and historical examination of nonprofit-government relationship the United States. In Boris, E. T., \& Steuerle, E.C. (eds.), Nonprofits \& government (pp. 31-67) Washington, DC: The Urban Institute. 
